\title{
HUBUNGAN ANTARA KREDIBILITAS PETUGAS PELAYANAN INFORMASI PUSKESMAS DENGAN SIKAP PENGUNJUNG TERHADAP PUSKESMAS NAGREG
}

\author{
Iin Sumiyati, Lukiati Komala, Yanti Setianti \\ Program Studi Hubungan Masyarakat Fikom Unpad \\ yantisetianti@gmail.com
}

\begin{abstract}
One of the most essential community services is the health-care service. Since, basically everyone needs a healthy physic to run all activities, so he could live his daily life well. Therefore, the best and trustworthy health-care service for community is essentially needed. The purpose of this research is to reveal the relation of the Informational service officers5' skills, interests, and trusts on patients/visitors' attitude toward the Local Integrated Service Unit of the Community Health Clinics in Nagreg. For the research, writer used the Correlational Quantitative Method, which is revealing the relation between one variable with the others. The result of the research shown that there's a significant relationship between the Informational service officers' skills, on patients/visitors' attitude toward the Local Integrated Service Unit of the Community Health Clinics in Nagreg. Which means that the higher skill of the Informational service officers have, the better attitude will be shown by the patients/visitors in the Local Integrated Service Unit of the Community Health Clinics in Nagreg. The officers' appeals can also increase the patients/visitors' positive attitude. And also, the more trustworthy the officers are, the more positive attitude will be shown by the patients/visitors toward the Informational service in the Local Integrated Service Unit of the Community Health Clinics in Nagreg.
\end{abstract}

Keywords : Credibility, Attitude, The Informational Service Officers.

\begin{abstract}
ABSTRAK
Salah satu layanan yang penting untuk masyarakat adalah layanan kesehatan. Sebab pada dasarnya setiap orang membutuhkan tubuh yang sehat dalam menjalankan setiap aktifitasnya sehingga mereka dapat melakukan kegiatannya dengan baik. Maka dari itu dibutuhkan layanan kesehatan yang optimal dan jaminan kepercayaan dari masyarakat. Penelitian ini bertujuan untuk mengetahui hubungan antara keahlian, daya tarik, keterpercayaan petugas pelayanan informasi dengan sikap pengunjung terhadap Unit Pelaksana Teknis Dinas Kabupaten/Kota (UPTD) Puskesmas Nagreg. Dalam penelitian ini, penulis menggunakan metode kuantitatif korelasional, yaitu mencari hubungan antara variabel satu dengan variabel lainnya. Hasil dari penelitian
\end{abstract}


ini adalah Terdapat hubungan yang cukup berarti antara keahlian petugas pelayanan informasi dengan sikap pasien terhadap UPTD Puskesmas Nagreg. Artinya semakin tinggi kemampuan yang dimiliki oleh petugas pelayanan informasi, maka akan meningkat pula sikap pengunjung terhadap petugas pelayanan informasi di UPTD Puskesmas Nagreg. Terdapat hubungan yang cukup berarti antara daya tarik petugas pelayanan informasi dengan sikap pasien terhadap UPTD Puskesmas Nagreg. Artinya semakin tinggi daya tarik yang dimiliki oleh petugas pelayanan informasi maka akan meningkat pula sikap pengunjung yang positif terhadap pelayanan informasi di UPTD Puskesmas Nagreg. Terdapat hubungan yang cukup berarti antara kepercayaan petugas pelayanan informasi dengan sikap pengunjung di UPTD Puskesmas Nagreg. Artinya semakin tinggi kepercayaan yang dimiliki oleh petugas petugas pelayanan informasi maka akan semakin meningkat pula sikap pengunjung yang positif terhadap pelayanan informasi di UPTD Puskesmas Nagreg.

\section{Kata Kunci: Kredibilitas, Sikap, Petugas Pelayanan Informasi}

\section{PENDAHULUAN}

Salah satu layanan yang penting untuk masyarakat adalah layanan kesehatan. Sebab pada dasarnya setiap orang membutuhkan tubuh yang sehat dalam menjalankan setiap aktifitasnya sehingga mereka dapat melakukan kegiatannya dengan baik. Maka dari itu dibutuhkan layanan kesehatan yang optimal dan jaminan kepercayaan agar masyarakat mendapat hasil yang memuaskan.

Dewasa ini sektor jasa telah mengalami perkembangan yang sangat pesat, seperti yang terjadi pada industri jasa Perhotelan, Asuransi, Perbankan, Penerbangan, Pariwisata dan Telekomunikasi. Demikian pula pada industri jasa kesehatan, apakah itu Rumah Sakit maupun Puskesmas, agar usaha tersebut bisa hidup dan berkembang diperlukan pengetahuan tentang pelayanan yang baik dan kepercayaan dari pasien.

Faktor lain yang dapat mempengaruhi tingkat kepuasan pengunjung adalah kepercayaan pengunjung. Kepercayaan pengunjung akan timbul karena ada keyakinan bahwa petugas pelayanan informasi dapat memberikan pelayanan informasi dengan baik dan benar. Keyakinan ini akan menimbulkan hubungan baik antara pihak yang terlibat pertukaran. Jika salah satu pihak percaya bahwa tindakan pihak 
lain akan membawa hasil positif untuk pihak pertama, kepercayaan dapat dikembangkan. Karena dengan adanya petugas pelayanan informasi, tentu akan berpengaruh terhadap opini pengunjung mengenai perusahaan itu sendiri dan akan menimbulkan persepsi yang baik pula.

\section{UPTD Puskesmas Nagreg} merupakan salah satu Puskesmas yang berada di Kabupaten Bandung. Puskesmas Nagreg selalu dijadikan pusat rujukan pertama dalam menangani masalah kesehatan yang ada di wilayah sekitar. Rendahnya citra Puskesmas yang selama ini berkembang di masyarakat seperti obat-obatan yang kurang bermutu dari segi variasi, petugas yang kurang tanggap dengan pasien, keramahan yang kurang dari pemberi layanan menimbulkan keraguan masyarakat terhadap mutu pelayanan Puskesmas.

Salah satu dari sekian banyak penilaian pelanggan terhadap sebuah perusahaan atau organisasi adalah mengenai pelayanan informasi. Bentuk pelayanan informasi suatu perusahaan atau organisasi akan terbentuk ketika mereka memberikan pelayanan dan akan menimbulkan kesan tertentu kepada para pelanggannya, sehingga akan terbentuk opini di antara mereka, dan nantinya mereka akan menentukan sikapnya terhadap perusahaan atau organisasi tersebut. Oleh karena itulah dibutuhkan orang-orang yang kredibel dalam pemberian informasi sehingga pengunjung yang membutuhkan informasi dapat mudah bertanya dan mendapatkan jawaban yang pasti dan meyakinkan sehingga akan membentuk sikap pengunjung itu sendiri.

Petugas Pelayanan Informasi yang seharusnya bertugas untuk melayani, memberi informasi tentang pelayanan dan fasilitas serta menciptakan hubungan yang harmonis dengan para pangunjung atau calon pasien. Karena petugas pelayanan informasi disini bertindak sebagai fasilisator yang dapat dipastikan harus memiliki kredibilitas yang baik yang cukup representative. 
penelitian ini berpijak pada Teori Kredibilitas Sumber (the source of credibility theory) yang dikemukakan oleh Hovland, Janis and Kelley pada tahun 1953.

\section{KAJIAN PUSTAKA}

Dalam bukunya Communications and Persuation, teori ini menjelaskan bahwa :

"people are more likely to be persuased when the source present its self as credible. Seseorang dimungkinkan lebih mudah dibujuk atau dipersuasi jika sumber-sumber persuasinya (komunikator) cukup kredibel".

Studi mengenai kredibilitas sumber pertama kali dilakukan di Yale oleh Hovland dan Weiss pada tahun 1951. Kesimpulan dari eksperimen yang Hovland dan Weiss adalah sebagai berikut :

"first, the study show that high credibility source produce more attitude change than low credibility source immediately often presentation of the message. Second, agreement with credible source decrease over time (four weeks). This change is greater than the change in low credibility source. And third, credibility of the source does not affect the message recall (Tan, 1981:133)".

Hovland menyatakan bahwa sumber komunikasi yang memiliki kredibilitas tinggi akan lebih efektif dalam mengubah opini seseorang dibadingkan dengan sumber komunikasi yang kredibilitas rendah. Hovland menggambarkan, "peranan kredibilitas dalam proses penerimaan pesan dengan mengemukakan bahwa para ahli akan lebih persuasif dibandingkan orang yang bukan ahli. Suatu pesan persuasi akan lebih efektif apabila kita mengetahui bahwa penyampaian pesan adalah orang yang ahli dibidangnya" (Azwar, 2005:6465). Efektivitas sebuah komunikasi 
sehingga di asumsikan tergantung pada siapa yang menyampaikan.

Kredibilitas sumber mengacu pada tingkat dimana penerima merasa sumber, atau pastisipan dalam proses komunikasi, seperti dapat dan merasa untuk memberi opini objektif dan seperti pemberian keahlian yang cukup relevan. Kredibilitas sumber menyeimbangkan efektivitas daya tarik rasa takut. Bila kredibilitas sumber tinggi, daya tarik rasa takut akan menyebabkan perubahan sikap seseorang.

Dalam kegiatan proses komunikasi seorang komunikator akan sukses apabila ia dapat menunjukan source credibility yang berarti ia dapat menjadi sumber kepercayaan bagi khalayaknya. Selain itu, ia harus dapat membuat khalayak tertarik akan dirinya terutama tentang apa yang akan disampaikannya.

Selanjutnya Tan (1981:104), menyatakan bahwa kredibilitas sumber terdiri dari tiga komponen yaitu keahlian, keterpercayaan, dan daya tarik. Keahlian (expertise) adalah tingkat dimana sumber di anggap cerdas, ahli dan berpengalaman. Jadi, seorang sumber yang dikatakan ahli adalah seorang ahli yang pengetahuannya yang di akui dan dipercaya tentang pokok permasalahan. Indikator dari komponen ini dapat di ukur apabila komunikator di anggap cerdas, ahli dan berpengalaman. Dalam penelitian ini, peneliti melakukan penelitian terhadap kredibilitas pelayanan informasi di Puskesmas Nagreg. Kredibilitas petugas pelayanan informasi dibutuhkan dalam menangani segala keluhan pasien.

Sedangkan keterpercayaan (trustoworthiness) adalah tingkat dimana seorang sumber dipersepsi sebagai yang memotivasi untuk mengkomunikasikan pendiriannya tanpa prasangka. Keterpercayaan berkaitan dengan penilaian khalayak bahwa sumber informasi di anggap tulus, jujur, adil, dan etis. (Venus, 2004:57) faktor keterpercayaan adalah faktor penting dalam kredibilitas sumber. Dalam penelitian ini factor 
keterpercayaan yang dimiliki oleh petugas pelayanan informasi sangatlah penting dalam menangani pengunjung. Petugas pelayanan informasi harus jujur dalam menyampaikan informasi, tulus, adil dan harus memiliki etika dalam menjalankan tugasnya.

Adapula daya tarik, yaitu mencangkup kesamaan, familiaritas dan kesukaan. Sebagaimana dijelaskan oleh Umar, dengan adanya kesamaan frame of reference dan kedekatan antara komunikator dan pengunjung, akan semakin mudah bagi komunikator untuk menyampaikan materi sehingga tujuan pun akan tercapai (Umar 2002:7).

Sikap yang di ungkap oleh Rahmat, memiliki beberapa anggapan. Pertama, sikap adalah kecenderungan bertindak, berpersepsi, berpikir dan merasa dalam memahami objek, ide, situasi, nilai. Sikap bukan perilaku, tetapi merupakan kecenderungan untuk berperilaku dengan cara-cara tertentu terhadap objek sikap. Kedua, sikap mempunyai daya pendorong atau motivasi. Ketiga, sikap relatif lebih menetap.

Sikap manusia adalah bentuk evaluasi atau reaksi perasaan, sikap seseorang terhadap suatu objek adalah perasaan mendukung atau memihak maupun perasaan tidak mendukung atau tidak memihak.

Dalam penelitian ini penulis menghubungkan antara kredibilitas petugas pelayanan informasi dengan sikap dimana sumber komunikasi yaitu petugas pelayanan informasi yang memiliki kredibilitas tinggi akan lebih efektif dalam mengubah sikap komunikan, yang disini adalah pengunjung, dibandingkan dengan sumber komunikasi yang berkredibilitas rendah, dan sumber yang memiliki kredibilitas tinggi dapat lebih banyak menghasilkan perubahan sikap dibanding sumber yang memiliki kredibilitas rendah.

Dalam penelitian ini sikap yang diteliti adalah sikap pengunjung terhadap kredibilitas petugas pelayanan informasi dimana petugas pelayanan merupakan ujung tombak 
dalam memberikan informasi kepada pengunjung yang datang ke Puskesmas Nagreg. Kredibilitas petugas mempengaruhi sikap pengunjung yang suka atau tidak, senang atau tidak senang terhadap perusahaan, yang nantinya akan berpengaruh untuk keberlangsungan Puskesmas.

Dengan adanya hubungan baik tersebut akan dapat menarik minat dan perhatian masyarakat untuk mengunjungi puskesmas yang dijadikan rujukan pertama ketika mengalami masalah kesehatan. Akan tetapi tumbuhnya minat dan perhatian masyarakat untuk mengunjungi puskesmas tidak akan muncul dengan sendirinya jika tidak terdapat "kepuasan" di hati masyarakat atau pasien. Kepuasan dapat diperoleh dari pelayanan yang diberikan oleh pelayanan informasi di Puskesmas Nagreg.

Adapun tujuan dari penelitian ini adalah untuk mengetahui hubungan antara keahlian, daya tarik dan keterpercayaan petugas pelayanan informasi dengan aspek kognisi, afeksi

dan konasi dari pengunjung UPTD Puskesmas Nagreg.

\section{METODE PENELITIAN}

Penelitian ini menggunakan penelitian korelasional yaitu penelitian yang melibatkan hubungan satu atau lebih variabel dengan satu atau lebih variabel lain. Bentuk hubungan dalam penelitian ini adalah Bivaret, yaitu hubungan yang melibatkan satu variabel bebas dengan satu variabel terikat (Purwanto, 2010:1770.

Penelitian korelasional melibatkan pengumpulan data untuk menentukan apakah terdapat hubungan antara dua atau lebih variabel serta seberapa besar tingkatan hubungan tersebut. Kaitannya dalam penelitian ini adalah untuk menyelidiki hubungan antara beberapa variabel penelitian yaitu variabel kredibilitas petugas pelayanan informasi puskesmas sebagai variabel predictor dengan sikap pengunjung terhadap UPTD Puskesmas Nagreg sebagai variabel criterion.

Teknik pengumpulan data yang digunakan dalam penelitian ini 
menggunakan 4 teknik yaitu angket (kuesioner) yang disebarkan kepada pengunjung Puskesmas Nagreg dan berdasarkan data pengunjung terbanyak di Puskesmas Nagreg yang diperoleh adalah 4169 orang pada bulan April, wawancara kepada para pengunjung, observasi dilapangan dan studi kepustakaan melalui buku-buku, jurnal dan penelitian sebelumnya.

\section{HASIL PENELITIAN DAN PEMBAHASAN}

Untuk mengetahui hubungan natara kredibilitas petugas pelayanan informasi puskesmas dengan sikap pengunjung terhadap UPTD
Puskesmas Nagreg. Hipotesis penelitian:

$\begin{array}{rlr}\mathrm{H}_{0}: \rho=0 & \text { (tidak } & \text { terdapat } \\ & \text { hubungan } & \text { kredibilitas } \\ & \text { pelayanan } & \text { informasi } \\ & \text { puskesmas } & \text { dengan } \\ & \text { sikap } & \text { pengungjung } \\ & \text { terhadap } & \text { UPTD } \\ & \text { Puskesmas } & \text { Nagreg) } \\ \mathrm{H}_{1}: \rho \neq 0 & \text { (terdapat } & \text { hubungan } \\ & \text { kredibilitas } & \text { petugas } \\ & \text { pelayanan } & \text { informasi } \\ & \text { puskesmas } & \text { dengan } \\ & \text { sikap } & \text { pengunjung } \\ & \text { terhadap } & \text { UPTD } \\ & \text { Puskesmas } & \text { Nagreg) }\end{array}$

Tabel 1

Hubungan Kredibilitas Petugas Pelayanan Informasi Puskesmas dengan Sikap Pengunjung Terhadap UPTD Puskesmas Nagreg

\begin{tabular}{|c|c|c|c|c|}
\hline Variabel & Rs & $\mathbf{t}_{\text {hitung }}$ & $\mathbf{t}_{\text {tabel }}$ & Keputusan \\
\hline Kredibilitas Pelayanan Informasi & 0.756 & 9.240 & 1.998 & $\mathrm{H}_{0}$ ditolak \\
Puskesmas dengan Sikap Pengunjung & & & & \\
Terhadap UPTD Puskesmas Nagreg & & & & \\
\hline
\end{tabular}
Sumber : Pengolahan Data 2017

Pada tabel 1 dapat dilihat adalah sebesar 0.756. Hasil uji koefisien korelasi Rank Spearman (rs) signifikansi diperoleh nilai t hitung 
sebesar 9.240dan nilai $\mathrm{t}$ tabel dengan $\alpha$ $=5 \%$ dan $\mathrm{dk}$ (derajat kebebasan $)=\mathrm{n}$ $2=64$ adalah sebesar 1.998 maka dapat dilihat bahwa $t$ hitung (9.240) $>\mathrm{t}$ tabel (1.998) sehinga $\mathrm{H}_{0}$ ditolak. Dengan demikian dapat diambil keputusan bahwa terdapat hubungan yang signifikan kredibilitas petugas pelayanan informasi puskesmas dengan sikap pengunjung terhadap UPTD Puskesmas Nagreg. Koefisien korelasi sebesar 0.756 menunjukkan keeratan hubungan kredibilitas pelayanan informasi puskesmas dengan sikap pengunjung terhadap UPTD Puskesmas Nagreg merupakan hubungan yang tinggi.

Untuk mengetahui hubungan keahlian petugas dengan aspek afeksi, peneliti menggunakan analisis data dengan koefisien korelasi Rank Spearman (rs). Hasil perhitungan dapat dilihat pada tabel di bawah ini.

Tabel 2

Hubungan Keahlian Petugas Pelayanan Informasi dengan Aspek Kognisi

\begin{tabular}{|c|c|c|c|c|}
\hline Variabel & rs & thitung & tabel & Keputusan \\
\hline Keahlian Pelayanan Informasi Puskesmas & 0.563 & 5.450 & 1.998 & $\mathrm{H}_{0}$ ditolak \\
dengan Aspek Kognisi Pengunjung & & & & \\
Terhadap UPTD Puskesmas Nagreg & & & & \\
\hline
\end{tabular}

Sumber : Pengolahan Data 2017

Pada tabel 2 dapat dilihat koefisien korelasi Rank Spearman (rs) adalah sebesar 0.563. Hasil uji signifikansi diperoleh nilai $\mathrm{t}$ hitung sebesar 5.450 dan nilai $t$ tabel dengan $\alpha=5 \%$ dan $\mathrm{dk}$ (derajat kebebasan) $=$ $\mathrm{n}-2=64$ adalah sebesar 1.998 maka dapat dilihat bahwa $t$ hitung (5.450) $>\mathrm{t}$ tabel (1.998) sehinga $\mathrm{H}_{0}$ ditolak.
Dengan demikian dapat diambil keputusan bahwa terdapat hubungan yang signifikan keahlian petugas pelayanan informasi puskesmas dengan aspek kognisi pengunjung terhadap UPTD Puskesmas Nagreg. Koefisien korelasi sebesar 0.563 menunjukkan keeratan hubungan keahlian pelayanan informasi 
puskesmas dengan aspek kognisi hubungan yang cukup berarti.

Untuk mengetahui hubungan keahlian petugas dengan aspek afeksi, peneliti menggunakan analisis data dengan koefisien korelasi Rank Spearman (rs). Hasil perhitungan dapat dilihat pada tabel di bawah ini.

Tabel 3

Hubungan Keahlian Petugas Pelayanan Informasi dengan Aspek Afeksi

\begin{tabular}{|c|c|c|c|c|}
\hline Variabel & Rs & thitung & tabel & Keputusan \\
\hline Keahlian Pelayanan Informasi Puskesmas & 0.563 & 5.450 & 1.998 & $\mathrm{H}_{0}$ ditolak \\
dengan Aspek Afeksi Pengunjung & & & & \\
Terhadap UPTD Puskesmas Nagreg & & & & \\
\hline
\end{tabular}

Sumber : Pengolahan Data 2017

Pada tabel 3 dapat dilihat koefisien korelasi Rank Spearman (rs) adalah sebesar 0.563. Hasil uji signifikansi diperoleh nilai $\mathrm{t}$ hitung sebesar 5.450 dan nilai t tabel dengan $\alpha=5 \%$ dan $\mathrm{dk}$ (derajat kebebasan) $=$ $\mathrm{n}-2=64$ adalah sebesar 1.998 maka dapat dilihat bahwa t hitung (5.450) > t tabel (1.998) sehinga $\mathrm{H}_{0}$ ditolak. Dengan demikian dapat diambil keputusan bahwa terdapat hubungan yang signifikan keahlian petugas pelayanan informasi puskesmas dengan aspek afeksi pengunjung terhadap UPTD Puskesmas Nagreg. Koefisien korelasi sebesar 0.563 menunjukkan keeratan hubungan keahlian pelayanan informasi puskesmas dengan aspek afeksi terdapat hubungan yang cukup berarti.

Untuk mengetahui hubungan keahlian petugas dengan aspek konasi, peneliti menggunakan analisis data dengan koefisien korelasi Rank Spearman (rs). Hasil perhitungan dapat dilihat pada tabel di bawah ini.

\section{Tabel 4}

Hubungan Keahlian Petugas Pelayanan Informasi dengan Aspek Konasi 


\begin{tabular}{|c|c|c|c|c|}
\hline Variabel & Rs & thitung $_{\text {t }}$ & tabel & Keputusan \\
\hline Keahlian Pelayanan Informasi Puskesmas & 0.360 & 3.087 & 1.998 & $\mathrm{H}_{0}$ ditolak \\
dengan Aspek Konasi Pengunjung & & & & \\
Terhadap UPTD Puskesmas Nagreg & & & & \\
\hline
\end{tabular}

Sumber : Pengolahan Data 2017

Pada tabel 4 dapat dilihat koefisien korelasi Rank Spearman (rs) adalah sebesar 0.360. Hasil uji signifikansi diperoleh nilai $\mathrm{t}$ hitung sebesar 3.087 dan nilai t tabel dengan $\alpha=5 \%$ dan $\mathrm{dk}$ (derajat kebebasan) $=$ n-2= 64 adalah sebesar 1.998 maka dapat dilihat bahwa t hitung (3.087) > t tabel (1.998) sehinga $\mathrm{H}_{0}$ ditolak. Dengan demikian dapat diambil keputusan bahwa terdapat hubungan yang signifikan keahlian petugas pelayanan informasi puskesmas dengan aspek konasi pengunjung

Tabel 5

Hubungan Daya Tarik Petugas Pelayanan Informasi dengan Aspek Kognisi

\begin{tabular}{|c|c|c|c|c|}
\hline Variabel & rs & thitung $_{\text {t }}$ & $\mathbf{t}_{\text {tabel }}$ & Keputusan \\
\hline Daya Tarik Pelayanan Informasi & 0.457 & 4.110 & 1.998 & $\mathrm{H}_{0}$ ditolak \\
Puskesmas dengan Aspek Kognisi & & & & \\
Pengunjung Terhadap UPTD Puskesmas \\
Nagreg & & & & \\
\hline
\end{tabular}

Sumber : Pengolahan Data 2017 
Pada tabel 5 dapat dilihat koefisien korelasi Rank Spearman (rs) adalah sebesar 0.457. Hasil uji signifikansi diperoleh nilai $\mathrm{t}$ hitung sebesar 4.110 dan nilai t tabel dengan $\alpha=5 \%$ dan $\mathrm{dk}$ (derajat kebebasan) $=$ $\mathrm{n}-2=64$ adalah sebesar 1.998 maka dapat dilihat bahwa t hitung (4.110) $>\mathrm{t}$ tabel (1.998) sehinga $\mathrm{H}_{0}$ ditolak. Dengan demikian dapat diambil keputusan bahwa terdapat hubungan yang signifikan daya tarik petugas pelayanan informasi puskesmas dengan aspek kognisi pengunjung terhadap UPTD Puskesmas Nagreg. Koefisien korelasi sebesar 0.457 menunjukkan keeratan hubungan daya tarik pelayanan informasi puskesmas dengan aspek kognisi terdapat hubungan yang cukup berarti.

Untuk mengetahui hubungan daya tarik dengan aspek afeksi, peneliti menggunakan analisis data dengan koefisien korelasi Rank Spearman (rs). Hasil perhitungan dapat dilihat pada tabel di bawah ini.

\section{Tabel 6}

Hubungan Daya Tarik Petugas Pelayanan Informasi dengan Aspek

Afeksi

\begin{tabular}{|c|c|c|c|c|}
\hline Variabel & rs & thitung $_{\text {tabel }}$ & Keputusan \\
\hline Daya Tarik Pelayanan Informasi & 0.457 & 4.110 & 1.998 & $\mathrm{H}_{0}$ ditolak \\
Puskesmas dengan Aspek Afeksi & & & & \\
Pengunjung Terhadap UPTD Puskesmas \\
Nagreg & & & & \\
\hline
\end{tabular}

Sumber : Pengolahan Data 2017

Pada tabel 6 dapat dilihat koefisien korelasi Rank Spearman (rs) adalah sebesar 0.457. Hasil uji signifikansi diperoleh nilai $\mathrm{t}$ hitung sebesar 4.110 dan nilai t tabel dengan $\alpha=5 \%$ dan $\mathrm{dk}$ (derajat kebebasan $)=$ $\mathrm{n}-2=64$ adalah sebesar 1.998 maka dapat dilihat bahwa t hitung (4.110) > t tabel (1.998) sehinga $\mathrm{H}_{0}$ ditolak. Dengan demikian dapat diambil 
keputusan bahwa terdapat hubungan yang signifikan daya tarik petugas pelayanan informasi puskesmas dengan aspek afeksi pengunjung terhadap UPTD Puskesmas Nagreg. Koefisien korelasi sebesar 0.457 menunjukkan keeratan hubungan daya tarik pelayanan informasi puskesmas dengan aspek afeksi terdapat hubungan yang cukup berarti.

Untuk mengetahui hubungan daya tarik dengan aspek konasi, peneliti menggunakan analisis data dengan koefisien korelasi Rank Spearman (rs). Hasil perhitungan dapat dilihat pada tabel di bawah ini.

\section{Tabel 7}

Hubungan Daya Tarik Petugas Pelayanan Informasi dengan Aspek Konasi

\begin{tabular}{|c|c|c|c|c|}
\hline Variabel & rs & thitung & $\mathbf{t}_{\text {tabel }}$ & Keputusan \\
\hline Daya Tarik Pelayanan Informasi & 0.630 & 6.490 & 1.998 & $\mathrm{H}_{0}$ ditolak \\
Puskesmas dengan Aspek Konasi & & & & \\
Pengunjung Terhadap UPTD Puskesmas \\
Nagreg
\end{tabular}

Sumber : Pengolahan Data 2017

Pada tabel 7 dapat dilihat koefisien korelasi Rank Spearman (rs) adalah sebesar 0.630. Hasil uji signifikansi diperoleh nilai $\mathrm{t}$ hitung sebesar 6.490 dan nilai $t$ tabel dengan $\alpha=5 \%$ dan dk (derajat kebebasan) $=$ $\mathrm{n}-2=64$ adalah sebesar 1.998 maka dapat dilihat bahwa t hitung (6.490) > t tabel (1.998) sehinga $\mathrm{H}_{0}$ ditolak. Dengan demikian dapat diambil keputusan bahwa terdapat hubungan yang signifikan daya tarik petugas pelayanan informasi puskesmas dengan aspek konasi pengunjung terhadap UPTD Puskesmas Nagreg. Koefisien korelasi sebesar 0.630 menunjukkan keeratan hubungan daya tarik pelayanan informasi puskesmas dengan aspek konasi terdapat hubungan yang cukup berarti.

Untuk mengetahui hubungan keterpercayaan dengan aspek kognisi, peneliti menggunakan analisis data dengan koefisien korelasi Rank 


\section{Tabel 8}

Hubungan Keterpercayaan Petugas Pelayanan Informasi dengan Aspek Kognisi

\begin{tabular}{|c|c|c|c|c|}
\hline Variabel & rs & thitung & $\mathbf{t}_{\text {tabel }}$ & Keputusan \\
\hline Keterpercayaan Pelayanan Informasi & 0.423 & 3.743 & 1.998 & $\mathrm{H}_{0}$ ditolak \\
Puskesmas dengan Aspek Kognisi & & & & \\
Pengunjung Terhadap UPTD Puskesmas \\
Nagreg & & & & \\
\hline
\end{tabular}

Sumber : Pengolahan Data 2017

$$
\text { Pada tabel } 8 \text { dapat dilihat pengunjung terhadap UPTD }
$$

koefisien korelasi Rank Spearman (rs) Puskesmas Nagreg. Koefisien korelasi adalah sebesar 0.423. Hasil uji signifikansi diperoleh nilai $\mathrm{t}$ hitung sebesar 3.743 dan nilai t tabel dengan $\alpha=5 \%$ dan $\mathrm{dk}$ (derajat kebebasan) $=$ $\mathrm{n}-2=64$ adalah sebesar 1.998 maka dapat dilihat bahwa t hitung (3.743) > t tabel (1.998) sehinga $\mathrm{H}_{0}$ ditolak. Dengan demikian dapat diambil keputusan bahwa terdapat hubungan yang signifikan keterpercayaan petugas pelayanan informasi sebesar 0.423 menunjukkan keeratan hubungan keterpercayaan pelayanan informasi puskesmas dengan aspek kognisi terdapat hubungan yang cukup berarti.

Untuk mengetahui hubungan keterpercayaan dengan aspek afeksi, peneliti menggunakan analisis data dengan koefisien korelasi Rank Spearman (rs). Hasil perhitungan dapat puskesmas dengan aspek kognisi

Tabel 9

Hubungan Keterpercayaan Petugas Pelayanan Informasi dengan Aspek Afeksi

\begin{tabular}{|l|c|c|c|c|}
\hline Variabel & rs & thitung & $\mathbf{t}_{\text {tabel }}$ & Keputusan \\
\hline
\end{tabular}




\begin{tabular}{|c|c|c|c|c|}
\hline Keterpercayaan Pelayanan Informasi & 0.516 & 5.819 & 1.998 & $\mathrm{H}_{0}$ ditolak \\
Puskesmas dengan Aspek Afeksi & & & & \\
Pengunjung Terhadap UPTD Puskesmas \\
Nagreg & & & & \\
\hline
\end{tabular}

Sumber : Pengolahan Data 2017

Pada tabel 9 dapat dilihat koefisien korelasi Rank Spearman (rs) adalah sebesar 0.516. Hasil uji signifikansi diperoleh nilai $\mathrm{t}$ hitung sebesar 5.819 dan nilai t tabel dengan $\alpha=5 \%$ dan $\mathrm{dk}$ (derajat kebebasan) $=$ n-2= 64 adalah sebesar 1.998 maka dapat dilihat bahwa t hitung (5.819) $>\mathrm{t}$ tabel (1.998) sehinga $\mathrm{H}_{0}$ ditolak. Dengan demikian dapat diambil keputusan bahwa terdapat hubungan yang signifikan keterpercayaan petugas pelayanan informasi puskesmas dengan aspek afeksi pengunjung terhadap UPTD Puskesmas Nagreg. Koefisien korelasi sebesar 0.516 menunjukkan keeratan hubungan keterpercayaan pelayanan informasi puskesmas dengan aspek afeksi terdapat hubungan yang cukup berarti.

Untuk mengetahui hubungan keterpercayaan dengan aspek afeksi, peneliti menggunakan analisis data dengan koefisien korelasi Rank Spearman (rs). Hasil perhitungan dapat dilihat pada tabel di bawah ini.

Tabel 10

Hubungan Keterpercayaan Petugas Pelayanan Informasi dengan Aspek Konasi

\begin{tabular}{|c|c|c|c|c|}
\hline Variabel & rs & thitung & t tabel & Keputusan \\
\hline Keterpercayaan Pelayanan Informasi & 0.532 & 5.026 & 1.998 & $\mathrm{H}_{0}$ ditolak \\
Puskesmas dengan Aspek Konasi & & & & \\
Pengunjung Terhadap UPTD Puskesmas \\
Nagreg
\end{tabular}

Sumber : Pengolahan Data 2017 
Pada tabel 10 dapat dilihat koefisien korelasi Rank Spearman (rs) adalah sebesar 0.532. Hasil uji signifikansi diperoleh nilai $\mathrm{t}$ hitung sebesar 5.026 dan nilai t tabel dengan $\alpha=5 \%$ dan $\mathrm{dk}$ (derajat kebebasan) $=$ $\mathrm{n}-2=64$ adalah sebesar 1.998 maka dapat dilihat bahwa t hitung (5.026) > t tabel (1.998) sehinga $\mathrm{H}_{0}$ ditolak. Dengan demikian dapat diambil keputusan bahwa terdapat hubungan yang signifikan keterpercayaan petugas pelayanan informasi

puskesmas dengan aspek konasi pengunjung terhadap UPTD Puskesmas Nagreg. Koefisien korelasi sebesar 0.532 menunjukkan keeratan hubungan keterpercayaan pelayanan informasi puskesmas dengan aspek konasi terdapat hubungan yang cukup berarti.

Untuk lebih memudahkan dalam mengetahui hubungan antar variabel/sub variabel penelitian dapat dilihat dari tabel rangkuman di bawah ini.

\section{Tabel 11}

\section{Rekapitulasi Hasil Analisis Korelasi}

\begin{tabular}{|c|c|c|c|c|c|c|}
\hline No & Variabel & $\mathbf{R s}$ & thitung & $t_{\text {tabel }}$ & Hasil & Keterangan \\
\hline 1. & $\mathrm{X} \operatorname{dan} \mathrm{Y}$ & 0.756 & 9.240 & 1.998 & $\begin{array}{c}\mathrm{H}_{0} \\
\text { ditolak }\end{array}$ & $\begin{array}{c}\text { Terdapat hubungan } \\
\text { yang tinggi }\end{array}$ \\
\hline 2. & $\mathrm{X} 1$ dan Y1 & 0.563 & 5.450 & 1.998 & $\begin{array}{c}\mathrm{H}_{0} \\
\text { ditolak }\end{array}$ & $\begin{array}{c}\text { Hubungan yang } \\
\text { cukup berarti }\end{array}$ \\
\hline 3. & $\mathrm{X} 1$ dan $\mathrm{Y} 2$ & 0.563 & 5.450 & 1.998 & $\begin{array}{c}\mathrm{H}_{0} \\
\text { ditolak }\end{array}$ & $\begin{array}{c}\text { Hubungan yang } \\
\text { cukup berarti }\end{array}$ \\
\hline 4. & $\mathrm{X} 1$ dan $\mathrm{Y} 3$ & 0.360 & 3.087 & 1.998 & $\begin{array}{c}\mathrm{H}_{0} \\
\text { ditolak }\end{array}$ & $\begin{array}{c}\text { Hubungan rendah } \\
\text { tapi pasti }\end{array}$ \\
\hline 5. & $\mathrm{X} 2$ dan $\mathrm{Y} 1$ & 0.457 & 4.110 & 1.998 & $\begin{array}{c}\mathrm{H}_{0} \\
\text { ditolak }\end{array}$ & $\begin{array}{c}\text { Hubungan yang } \\
\text { cukup berarti }\end{array}$ \\
\hline 6. & $\mathrm{X} 2$ dan $\mathrm{Y} 2$ & 0.457 & 4.110 & 1.998 & $\mathrm{H}_{0}$ & Hubungan yang \\
\hline
\end{tabular}




\begin{tabular}{|c|c|c|c|c|c|c|}
\hline & & & & & ditolak & cukup berarti \\
\hline 7. & $\mathrm{X} 2$ dan Y3 & 0.630 & 6.490 & 1.998 & $\begin{array}{c}\mathrm{H}_{0} \\
\text { ditolak }\end{array}$ & $\begin{array}{c}\text { Hubungan yang } \\
\text { cukup berarti }\end{array}$ \\
\hline 8. & $\mathrm{X} 3$ dan $\mathrm{Y} 1$ & 0.423 & 3.743 & 1.998 & $\begin{array}{c}\mathrm{H}_{0} \\
\text { ditolak }\end{array}$ & $\begin{array}{c}\text { Hubungan yang } \\
\text { cukup berarti }\end{array}$ \\
\hline 9. & $\mathrm{X} 3$ dan Y2 & 0.516 & 5.819 & 1.998 & $\begin{array}{c}\mathrm{H}_{0} \\
\text { ditolak }\end{array}$ & $\begin{array}{c}\text { Hubungan yang } \\
\text { cukup berarti }\end{array}$ \\
\hline 10 & X3 dan Y3 & 0.532 & 5.026 & 1.998 & $\begin{array}{c}\mathrm{H}_{0} \\
\text { ditolak }\end{array}$ & $\begin{array}{c}\text { Hubungan yang } \\
\text { cukup berarti }\end{array}$ \\
\hline
\end{tabular}

Sumber : Pengolahan Data 2017

\section{PEMBAHASAN}

Penelitian ini memiliki tujuan untuk mengetahui hubungan antara kredibilitas petugas pelayanan informasi puskesmas dengan sikap pengunjung terhadap UPTD Puskesmas Nagreg. Penelitian ini dilakukan dengan metode korelasional untuk mencari hubungan diantara masing-masing.

Keahlian petugas pelayanan informasi UPTD Puskesmas Nagreg memiliki hubungan dengan aspek kognisi, afeksi dan konasi. Tingkat keahlian petugas pelayanan informasi UPTD Puskesmas Nagreg diukur dari indikator kemampuan petugas pelayanan informasi dalam menguasai informasi dan pengalaman petugas pelayanan informasi terkait UPTD Puskesmas Nagreg.

Aspek kognisi dilihat dari indikator pengetahuan, persepsi dan kepercayaan pengunjung terhadap puskesmas. Aspek afeksi dilihat dari indikator kenyamanan dan kepuasan pengunjung terhadap puskesmas. Aspek konasi dilihat dari indikator kesediaan pengunjung untuk menginformasikan mengenai UPTD Puskesmas Nagreg dan kesediaan untuk mengajak kerabat untuk 
menggunakan pelayanan informasi di UPTD Puskesmas Nagreg.

Hasil pengolahan data menunjukkan bahwa variabel keahlian petugas pelayanan informasi memiliki tingkat keeratan yang cukup berarti terhadap aspek kognisi dan afeksi tetapi dilihat dari variabel keahlian petugas pelayanan informasi memiliki keeratan yang rendah tapi pasti terhadap aspek konasi. Hal tersebut terlihat dari pengolahan data yang menunjukkan koefisien korelasi sebesar 0.563 untuk keeratan dengan aspek kognisi, 0.563 untuk keeratan dengan aspek afeksi dan 0.360 untuk keeratan rendah tapi pasti dengan aspek konasi.

Daya tarik petugas pelayanan informasi UPTD Puskesmas Nagreg memiliki hubungan dengan aspek kognisi, afeksi dan konasi. Tingkat daya tarik petugas pelayanan informasi dalam penelitian ini dilihat dari indikator penampilan fisik dan karakteristik kepribadian petugas pelayanan informasi. Hasil pengolahan data menunjukkan bahwa variabel keahlian petugas pelayanan informasi memiliki tingkat keeratan yang cukup berarti terhadap aspek kognisi, afeksi dan konasi dari pengunjung UPTD Puskesmas Nagreg. Hal tersebut terlihat dari hasil pengolahan data yang menunjukkan koefisien korelasi sebesar 0.457 untuk keeratan dengan aspek kognisi, 0.457 untuk keeratan dengan aspek afeksi dan 0.630 untuk keeratan dengan aspek konasi.

Keterpercayaan petugas pelayanan informasi UPTD Puskesmas Nagreg memiliki hubungan dengan aspek kognisi, afeksi dan konasi. Hasil pengolahan data yang menunjukkan bahwa keterpercayaan petugas pelayanan informasi memiliki tingkat keeratan yang cukup berarti terhadap aspek kognisi, afeksi dan konasi dari pengunjung UPTD Puskesmas Nagreg. Hal tersebut terlihat dari hasil pengolahan data yang menunjukkan koefisien korelasi sebesar 0.423 untuk keeratan dengan aspek kognisi, 0.516 untuk keeratan dengan aspek afeksi dan 0.532 untuk keeratan dengan aspek konasi. 


\begin{tabular}{|c|c|c|}
\hline “Kred & dibilitas & komunikator \\
\hline 106 & sepe & $\mathrm{p}$ \\
\hline omunikan & tentang & sifat-sifat \\
\hline xomunikator' & " (Rakhmat, & 2008:257) \\
\hline$S$ & $i b i$ & ility Theory \\
\hline fektivitas & komunikasi & ditentukar \\
\hline redibilitas & komunikator & yang \\
\hline alamnya & meliputi & ilaia! \\
\hline mun & pada & $\mathrm{Ke}$ \\
\hline
\end{tabular}

keterpercayaan dan daya tarik yang dimiliki oleh komunikator. "Keahlian adalah kesan yang dibentuk komunikator dalam hubungannya dengan materi yang dibicarakan" (Rakhmat , 2008:260). Selain itu, kredibilitas adalah bagaimana seorang komunikator ulung dinilai dan dipercaya oleh individu yang menerima komunikasi (Mar'at, 1981:58). Komunikator sendiri berarti seorang pembicara oleh individu yang mengkomunikasikan secara langsung kepada audiens mengenai pandangannya terhadap suatu isu. (Hovland, 1966:19).

Menurut Alexis Tan (1981:104), komunikator yang kredibel adalah komunikator yang ahli dan juga memiliki kejujuran. Faktor kredibilitas sumberterdiri dari seperangkat penilaian komunikan pada keahlian (experiness), sifat-sifat yang dapat dipercaya (trustworthiness) dan daya tarik (attractiveness) yang dimiliki oleh komunikator.

Sikap adalah kecenderungan bertindak, berpersepsi, berpikir, dan merasa dalam menghadapi objek, ide, situasi atau nilai. Sikap merupakan suatu pola perilaku, tendensi, atau kesiapan antisipatif, predisposisi untuk menyesuaikan diri dalam situasi sosial atau secara sederhana sikap adalah respons terhadap stimuli sosial yang telah terkondisikan. (Azwar, 2013:5)

Sikap seseorang terhadap suatu objek adalah perasaan mendukung atau memihak maupun tidak mendukung atau tidak memihak pada objek tersebut (Azwar, 2013:5). Sehingga dapat dikatakan bahwa sikap adalah respons terhadap stimuli sosial yang telah terkondisikan. Adapun definisi sikap menurut Secord \& Backman adalah keteraturan tertentu dalam pemikiran (kognisi), perasaan (afeksi), 
dan predisposisi tindakan (konasi) seseorang terhadap suatu aspek dilingkungan sekitarnya (Azwar, 2013:5). Jika dijabarkan lebih lanjut komponen sikap dapat diuraikan sebagai berikut:Kognisi

Komponen kognitif merupakan representasi apa yang dipercayai oleh individu pemilik sikap. Komponen kognitif adalah berisi kepercayaan seseorang mengenai apa yang berlaku atau apa yang benar mengenai objek sikap. Sekali kepercayaan itu telah terbentuk, maka itu telah terbentuk, maka ia akan menjadi dasar pengetahuan seseorang mengenai apa yang diharapkan objek tertentu. Aspek kognitif ini merupakan aspek penggerak perubahan karena informasi yang diterima menentukan perasaan dan kemauan berbuat. (Azwar, 2013:24)

Afeksi Komponen yang menyangkut masalah emosional subjektif seseorang terhadap suatu objek yang pada umumnya diwujudkan dalam bentuk perasaan positif dan negatif. Penjabaran perasaan positif kemudian diartikan sebagai perasaan senang yang dirasakan oleh individu sedangkan perasaan negatif sebagai perasaan tidak senang yang dirasakan oleh individu tersebut. (Azwar, 2013:26)

Konasi Komponen konatif berisi mengenai perilaku sikap yang menunjukkan bagaimana perilaku atau kecenderungan berperilaku yang ada dalam diri seseorang berkaitan dengan objek sikap yang dihadapinya. Kaitan ini didasari oleh asumsi bahwa kepercayaan dan perasaan banyak mempengaruhi perilaku. Kecenderungan berperilaku secara konsisten, selaras dengan kepercayaan dan perasaan ini membentuk sikap individual. (Azwar, 2013:27)

\section{SIMPULAN}

Berdasarkan hasil penelitian dan pembahasan mengenai hubungan antara kredibilitas petugas pelayanan informasi dengan sikap pengunjung terhadap UPTD Puskesmas Nagreg, maka pada bagian akhir dari penelitian ini, penulis menarik kesimpulan, 
sekaligus memberikan saran sebagai berikut.

\section{Simpulan}

1. Terdapat hubungan yang cukup berarti antara keahlian petugas pelayanan informasi dengan sikap pasien terhadap UPTD Puskesmas Nagreg. Artinya semakin tinggi kemampuan yang dimiliki oleh petugas pelayanan informasi, maka akan meningkat pula sikap pengunjung terhadap petugas pelayanan informasi di UPTD Puskesmas Nagreg.

2. Terdapat hubungan yang cukup berarti antara daya tarik petugas pelayanan informasi dengan sikap pasien terhadap UPTD Puskesmas Nagreg. Artinya semakin tinggi daya tarik yang dimiliki oleh petugas pelayanan informasi maka akan meningkat pula sikap pengunjung yang positif terhadap pelayanan informasi di UPTD Puskesmas Nagreg.
3. Terdapat hubungan yang cukup berarti antara kepercayaan petugas pelayanan informasi dengan sikap pengunjung di UPTD Puskesmas Nagreg. Artinya semakin tinggi kepercayaan yang dimiliki oleh petugas petugas pelayanan informasi maka akan semakin meningkat pula sikap pengunjung yang positif terhadap pelayanan informasi di UPTD Puskesmas Nagreg.

\section{SARAN}

Berdasarkan kesimpulan penelitian yang dipaparkan diatas, maka peneliti mengajukan saran sebagai berikut:

1. UPTD Puskesmas Nagreg hendaknya mengadakan evaluasi setidaknya satu bulan sekali untuk lebih meningkatkan dan mempertahankan kredibilitas petugas pelayanan informasi puskesmas yang bertujuan untuk mengupdate keahlian, daya tarik, dan keterpercayaan. Sehingga dapat berguna untuk 


\section{meningkatkan sikap \\ pengunjung terhadap UPTD \\ Puskesmas Nagreg.}

2. UPTD Puskesmas Nagreg

hendaknya mengadakan sebuah

pelatihan khusus untuk

meningkatkan keahlian petugas

pelayanan informasi

puskesmas, agar dapat

meningkatkan konasi pengunjung UPTD Puskesmas

Nagreg. Sehingga, pengunjung

UPTD bersedia

mengkonfirmasikan kepada

kerabat dan mengajak

kerabatnya untuk

menggunakan pelayanan

informasi UPTD Puskesmas

Nagreg.

\section{DAFTAR PUSTAKA}

Abdurahman, M., Muhidin, S. A., \& Somantri, A. 2011. Dasar-dasar MetodeStatistika.Bandung: CV Pustaka Setia.

Arikunto, Suharsimi. 1998. Prosedur Penelitian Suatu Pendekatan Praktek. Jakarta: PT. Rineka Cipta.

Azwar, S. 2005. Metode Penelitian. Yogyakarta: Pustaka Pelajar.

Azwar, S. 2013. Sikap Manusia Teori dan Pengukurannya. Yogyakarta: Pustaka Pelajar.

Bungin, Burhan. 2005. Metode Penelitian Kuantitatif:

Komunikasi Ekonomi dan
Kebijakan Publik Serta Ilmu-Ilmu Sosial Lainnya. Jakarta: Gramedia Pustaka.

Cangara, Hafied. 2007. Pengantar Ilmu Komunikasi. Jakarta: PT Raja Grafindo Persada.

Effendy, Onong Uchjana. 2003. Ilmu Teori, dan Filfasat Komunikasi. Bandung: PTCitra Aditya Bhakti.

Hovland, C. I., Janis, I. L., \& Kelley, H. H. 1953. Communcation and Persuasion. Yale University: New Haven.

Hurlock, Elizabeth. B. 1994. Psikologi Perkembangan. Jakarta: Erlangga.

Kaplan dan Saccuzo. 2012.

Pengukuran Psikologi: Prinsip, Penerapan, dan Isu.Jakarta:

Salemba Humaika. 
Kriyantono, Rachmat. 2006. Teknis Praktis Riset Komunikasi. Jakarta: Kencana Prenada Media Group.

Mar'at, P. D. 1981. Sikap Manusia Perubahan Serta Pengukurannya. Jakarta:Ghalia Indonesia.

Prasetyo, Bambang, Lina Miftahul Jannah. 2007. Metode Penelitian Kuantitatif:Teori dan Aplikasi. Jakarta: PT Raja Grafindo Persada.

Prijana, 2005. Metode Sampling Terapan. Bandung: Humaniora.

Rakhmat, J. 2008. Psikologi Komunikasi. Bandung: PT Remaja Rosdakarya.

Rakhmat, J. 2009. Metode Penelitian Komunikasi. Bandung: PT Remaja Rosdakarya.

Riduwan. 2010. Metode dan Teknik Menyusun Tesis. Bandung: Alfabeta

Siegel, Sydney. 1997. Statistik Non Parametrik Untuk Ilmu Sosial. Jakarta: PT Gramedia.
Singarimbun, Masri. 1989. Metode Penelitian Survey. Jakarta Barat: Pustaka LP3ES.

Sugiyono. 2012. Metode Penelitian Kuantitatif dan Kualitatif dan R\&D. Bandung:Alfabeta.

Tan, A. 1981. Mass Communication Theories And Research. Columbus Ohio: GritPublishing.

Venus, Antar. 2012. Manajemen Kampanye Panduan Teoritis dan Praktis dalam

Mengefektifkan Kampanye Komunikasi. Bandung: Simbiosa Rekatama Media.

Widjadja, H. A. W. 2000. Ilmu Komunikasi: Pengantar Studi. Jakarta: Rineka Cipta.

Zuhriah, Nurul. 2006. Metodologi Penelitian Sosial dan Pendidikan Teori Aplikasi. Jakarta: Bumi Aksara. 